\title{
Prediction of geomorphologic parameters of catchment without GIS to estimate runoff using GIUH model
}

3

(1)

${ }^{1}$ Department of civil engineering, Estahban Branch, Azad University, Estahban, Iran

* Corresponding Author: e-mail: water.estahban@yahoo.com

Tel: 00989173132092

Fax: 009871132360352

${ }^{2}$ Department of civil engineering, Estahban Branch, Azad University, Estahban, Iran

e-mail: tooraj419@yahoo.com

Tel: 00989177151596

\begin{abstract}
:
Estimation of flood in ungauged catchments has great importance in the design of hydraulic structures. The geomorphologic instantaneous unit hydrograph (GIUH) technique uses geomorphologic parameters to estimate catchment runoff. In this research, regression equations were developed based on geometrical characteristics of nine catchments such as area, length and slope of the main river to estimate geomorphologic data of other catchments with no need for GIS and digital elevation model. These equations were used for verification of stream-order-law ratios as well as geomorphologic parameters corresponding to the Gagas, Heng-Chi and Kasilain catchments. In this study, the effect of stream-order-law ratios on the rate of runoff in Kasilian catchment was examined, and the sensitivity of each ratio was analyzed. The GIUH model was assessed in two cases of GIS-supported and GIS-unsupported. The mean errors of the regression equations in estimation of ratios $R_{B}, R_{L}, R_{A}, R_{S}$ and $R_{S O}$ in three study catchments were $4.7 \%$, $23.5 \%, 7.1 \%, 41.3 \%$, and $22.9 \%$, respectively. The direct runoff hydrograph for the Heng-Chi and the Kasilian catchments were computed by GIUH model and compared with observed
\end{abstract}


runoff. According to the results, the errors of peak discharge for four rainfall-runoff events in GIS-unsupported case were, on average, $10 \%$ more than the error in the case of GIS-supported GIUH. The results of GIUH for the two cases are very close to each other. The mean coefficient of efficiency of the model was computed as 0.87 .

Key words: GIUH, GIS, Stream-order-law ratios, Geomorphologic parameters

\section{Introduction}

Estimation of design flood in catchments is a vital issue in design of flood control structures. Most catchments are ungauged and the statistical methods are not efficient, hence the rainfallrunoff models are employed to estimate runoff. GIUH is a rainfall-runoff model for estimating runoff in ungauged catchments using their geomorphologic parameters (GP).

Studies on streams orderings of catchments were first introduced by Horton (1932, 1945). Later, modifications were made on Horton's method by Strahler $(1952,1957,1964)$ leading to a new method of ordering.

The idea of GIUH was introduced by Rodriguez-Iturbe and Valdes (1979). They suggested an instantaneous unit hydrograph (IUH) model in which time to peak and peak flow of the catchment were functions of geomorphologic features. The geomorphologic parameters of the catchments are calculated by GIS software such as ArcGis and hydrologic extensions such as ArcHydro. For this purpose, DEM of the catchment is necessary. First, stream networks are delineated and, GP such as the number of streams, lengths, slopes, and drainage areas in each order of streams is carried out based on stream orderings (Horton-Strahler method). GIUH model was extended and used by other scientists in different catchments (e.g. Gupta et al. 1980; Rodriguez-Iturbeet al. 1982; Lee and Yen 1997 and Kumar and Kumar 2008).

An alternative approach was provided by Lee and Yen (1997). The travel times for different orders of overland areas and channels were derived using the kinematic-wave theory and then substituted into the GIUH model to develop a kinematic wave-based GIUH model for watershed runoff simulation.

4 Lee and Chang (2005) offered a GIUH model to estimate surface and subsurface flow of 5 catchments. In their research, special importance was given to separation of surface flow from 56 subsurface flow in catchments. Sabzevari et al. (2013) modified the model presented by Lee and 
57 Chang (2005) for estimation of surface and subsurface flow of Kasilian catchment. They have also given a saturation model for separation of saturated and unsaturated zones of overland regions.

Sabzevari and Norouzpoor (2014) suggested a GIUH model which is capable of taking plan shape and profile curvature in complex hillslopes in computation of surface and subsurface travel time. Also, the effect of geometry of complex hillslopes on the runoff in sub-catchment No. 125 of Walnut Gulch was investigated.

Kumar et al. $(2004,2007)$ rendered the runoff estimation of ungauged catchments by applying the GIUH-based Nash and Clark models. They used stream ratios to estimate Nash and Clark's parameters. Kumar and Kumar (2008) focused on estimation of runoff in Ramganga catchment, India, applying GIUH based on kinematic wave theory. The model was used in the cases where the inputs were geomorphologic parameters and stream-order-law ratios. Travel time of the streams and overland regions in the two above cases were given as analytic equations based on Horton-Strahler stream-ordering system.

Choi et al. (2011) used a concept of geomorphologic dispersion to estimate Nash model parameters from spatial heterogeneity of flow path within a catchment.

Based on GP of catchment, stream-order-law ratios such as bifurcation ratio $\left(R_{B}\right)$, stream-length ratio $\left(R_{L}\right)$, stream-area ratio $\left(R_{A}\right)$, and stream-slope $\left(R_{S}\right)$ ratio could be computed. According to the GIUH offered by Yen and Lee (1997), the travel times of overland region and stream could be worked out regarding stream-order-law ratios prior to IUH estimation.

Due to the lack of topographic map and DEM for most of the catchments, application of GISbased GIUH models is practically useless. One goal of this research is to provide a technique by which one could compute geomorphologic parameters without the need for GIS. Calculating the GP by means of GIS is costly and takes a long time. For example, extensions such as ArcHydro, though capable of calculating the number, length, and slope of streams at any order, provide no information about overland surface slopes or drainage area at any order which ought to be calculated manually by GIS specialists which is time consuming. For this purpose, GP of twelve catchments of various sizes with diverse stream networks were collected. The values of streamorder-law ratios and the actual GP of the catchments obtained from GIS were derived. 
86 To study the relation between data, linear and nonlinear regressions were used using the SPSS software. In general, length and slope of the main stream and area of the catchment are among the geometric parameters that are easily computable for every catchment. It is also important to present empirical equations which could predict all stream-order-law ratios based on the 90 geometrical catchment information.

91 The important aims of this research are:

(1) to present equations which can predict, without the use of GIS and DEM of the catchment, the stream-order-law ratios on the basis of length, slope of the main stream and area of catchment (geometrical features).

(2) to analyze sensitivity of stream ratios and its effect on direct runoff hydrograph (DRH).

(3) to estimate runoff of ungauged catchments by means of GIUH without the use of GIS.

\section{GIUH model}

Surface runoff of the overland regions moves, through stream networks, to the outlet of catchment. If a catchment is ordered via Strahler ordering scheme, the water travel paths from the overland regions to the outlet are specified. Each flow path is comprised of different states, the first of which is the overland region and the others are the streams. The probability of water motion in a certain path $w: x_{o_{i}} \rightarrow x_{i} \rightarrow x_{j} \rightarrow \ldots \rightarrow x_{\Omega}$ is expressed as:

$$
P(w)=P_{O A_{i}} P_{x_{i} x_{i}} P_{x_{i} x_{j}} \ldots P_{x_{k} x_{\Omega}}
$$

where $P_{O A_{i}}$ is the initial state probability of rain drop moving from $i$ th order overland region to the $i$ th order stream, which can be approximated as the ratio of $i$ th order overland area to the total catchment area; $P_{x_{o i} x_{i}}$ which is the probability of raindrop moving from $i$ th order overland region $\left(x_{o_{i}}\right)$ to $i$ th order stream equals one; and $P_{x_{i} x_{j}}$ is the transitional probability of rain drop moving from $i$ th order stream $\left(x_{i}\right)$ to $j$ th order channel $\left(x_{j}\right)$.

The number of streams at each order and how they are connected to each other specify the probabilities in Eq. (1). 
111 The value of IUH of a watershed comprising different runoff paths is given by Eq. (2)

112 (Rodriguez-Iturbe and Valdes 1979).

$113 u(t)=\sum_{w \in W}\left[f_{x_{o_{i}}}(t) * f_{x_{i}}(t) * f_{x_{j}}(t) * \ldots * f_{x_{\Omega}}(t)\right]_{w} \times P(w)$ where $f_{x_{k}}(t)$ denotes the travel time probability density function (PDF) in state $x_{k}$ with a mean travel time value $\left(T_{x_{k}}\right)$ and the function $f$ is indeed the IUH of any state $x_{k}$ calculated by the formula $f(t)=\left(1 / T_{x_{k}}\right) \exp \left(-t / T_{x_{k}}\right)$. The PDF is a function of the travel time of each state in the overland regions and streams. Asterisk (*) denotes a convolution integral. $w \in W, W$ being $W=\left\langle x_{o_{i}}, x_{i}, x_{j}, \ldots, x_{\Omega}\right\rangle, i=1,2,3, \ldots, \Omega$ and $t$ is the time.

To solve Eq. (2), one could resort to the Laplace transformations. In the process of GIUH derivation, computation of travel time is the most intricate part of the work because its value depends on GP of the catchment.

The ordinates of DRH for the catchment were estimated by convoluting the effective rainfall hyetograph with the derived IUH.

The equation for estimation of DRH is:

$Q(t)=\int_{0}^{t} u(t-\tau) I_{e}(\tau) d \tau$

where $I_{e}$ is the excess rainfall and $u(t)$ is the catchment IUH.

\subsection{Travel time of overland planes and streams}

According to the kinematic wave theory, the travel time of an overland plane depends on the length, slope, Manning coefficient, and excess rainfall intensity. Eq. (4) which is due to Yen and Lee (1997) gives the travel time of the $i$ th overland plane.

$$
T_{X_{o i}}=\left(\frac{n_{0} A P_{O A_{i}} \sum_{i=1}^{\Omega} R_{L}^{i-\Omega}}{2 a^{1 / 2} S_{c_{\Omega}}^{b / 2} L q_{L}^{m-1} R_{B}^{\Omega-i} R_{L}^{i-\Omega} R_{S}^{b(i-\Omega) / 2}}\right)^{1 / m}
$$


132

133

134

135

136

137

138

140

141

142

143

144

145

146

147

148

149

150

151

152

153

where $R_{B}, R_{L}, R_{A}$, and $R_{S}$ are bifurcation ratio, stream-length ratio, stream-area ratio, and streamslope ratio, respectively; $A$ is the area of the catchment; $a$ and $b$ are 5.463 and 1.083, respectively; $q_{L}$ is the excess rainfall intensity; $n_{0}$ is the Manning's roughness coefficient for overland flow; $S_{c \Omega}$ is slope of the highest order stream; the constant $m$ can be recognized as $5 / 3$ from Manning's equation and $L$ is sum of mean length of the streams of different orders.

The travel time of the $i$ th-order channel in each path is obtained, based on its GP, through Eq. (5) (Yen and Lee 1997):

$$
T_{X_{i}}=\frac{B_{\Omega} L R_{L}^{i-\Omega} R_{B}^{\Omega-i} \sum_{i=1}^{i} R_{L}^{i-\Omega}}{q_{L} A P_{O A_{i}}\left(\sum_{i=1}^{\Omega} R_{L}^{i-\Omega}\right)^{2}}\left[\left(h_{c c_{i}}^{m}+\frac{q_{L} A P_{O A_{i}} n_{c} \sum_{i=1}^{\Omega} R_{L}^{i-\Omega}}{B_{\Omega} S_{c_{\Omega}}^{1 / 2} R_{S}^{(i-\Omega) / 2} R_{B}^{\Omega-i} \sum_{i=1}^{i} R_{L}^{i-\Omega}}\right)^{1 / m}-h_{c c_{i}}\right]
$$

where $h_{c o_{i}}$ is the inflow depth of the $i$ th-order channel due to water transported from upstream reaches, is given as:

$$
h_{c o_{i}}=\left(\frac{q_{L} n_{c} A\left(R_{B}^{\Omega-i} R_{A}^{i-\Omega}-P_{O A_{A}}\right) \sum_{i=1}^{\Omega} R_{L}^{i-\Omega}}{S_{c_{\Omega}}^{1 / 2} B_{\Omega} R_{S}^{(i-\Omega) / 2} R_{B}^{\Omega-i} \sum_{i=1}^{i} R_{L}^{i-\Omega}}\right)^{1 / m}
$$

Where $n_{c}$ is the Manning coefficient of stream, $B_{\Omega}$ is the width of the stream. The value of $h_{c o i}$ is equal to zero for $i=1$.

\section{Geomorphologic parameters (GP)}

As observed in the Eqs. (5) and (6), the stream-order-law ratios particularly, $R_{S}, R_{A}, R_{L}, R_{B}$ are of high importance. These affect the travel time, IUH, and DRH; also, they are computed according to the GP. For this purpose, the stream network is delineated by means of GIS. In the GIS, the streams are ordered via Horton-Strahler method, and the number, length, and slope of the streams are calculated at each order.

The value of $R_{B}$ is given by the following equation regarding the number of stream segments at each order: 
$155 N_{i}$ denotes the number of $i$ th-order channels. The length ratio $\left(R_{L}\right)$ is:

$156 \quad R_{L}=\overline{L_{c_{i}}} / \overline{L_{c_{i-1}}} \quad, i=2,3, \ldots, \Omega$

$\overline{L_{c_{i}}}$ is the mean length of $i$ th-order channels. Eq. (9) yields the value of $R_{A}$ :

$158 \quad R_{A}=\overline{A_{i}} / \overline{A_{i-1}}$

159 where $\overline{A_{i}}$ is the mean area of catchment of order $i$. It should be noted that the mean area of a 160 given stream segment is, in fact, a cumulative value, for example, the area of a third-order 161 catchment is a sum of the areas of the first, second and third-order streams. Computation of $R_{A}$ is not so easy a task for the GIS users.

The value of $R_{S}$ depends on the streams slope and is obtained by Eq. (10):

where $\overline{S_{c_{i}}}$ is the mean slope of the $i$ th-order streams.

As a result of experiments in the natural catchments, the following ranges are observed:

$1673 \leq R_{B} \leq 5$ and $1.5 \leq R_{L} \leq 3.5$. Slope of the streams and overland planes for different catchments

168 at each order are different. The mean values of these slopes at each order take a considerable time to compute by GIS, especially in large catchments.

In this research, a new slope ratio named the overland slope ratio $\left(R_{S O}\right)$ is introduced that is given in terms of the mean slope of the overland plane by:

$172 R_{S O}=\overline{S_{o_{i-1}}} / \overline{S_{o_{i}}}$

173 where $\overline{S_{o_{i}}}$ is the mean slope of the $i$ th-order overland plane.

174 In this research we intend to find the relationship between $R_{S O}$ and the other stream-order-law 175 ratios. 
176 Herein, a way for computing GP via regression equations is sought. These equations attained by

177

178

179

180

181

182

183

184

185

186

187

188

189

190

191

192

193 regression methods work through statistical analysis of the information of catchments possessing geomorphologic attributes. The way these equations perform computations will be explained in the next sections.

\section{Case Study}

To study the relationship between geomorphologic parameters, knowledge of the GIS based GP (i.e the GP derived from GIS) of some natural catchments is required. This research uses information received from twelve catchments in different countries. Table (1) shows the GIS based GP along with stream order ratios of the case study catchments. The catchments Long chi (Shuyou et al. 2010); Long men (Shuyou et al. 2010); Chaukhutia (Kumar 2014); Al-Malaqi (Shadeed et al. 2007); Debarwa (Alemngus and Mathur 2014); Gherghera (Alemngus and Mathur 2014); San-Hsia (Chang and Lee 2008); Al-Badan (Shadeed et al. 2007); Al-Faria (Shadeed et al. 2007) were used for training and estimation of regression equations, and the Gagas (Kumar and Kumar 2008), Heng-Chi (Lee and Chang 2005) and Kasilian (Sabzevari et al 2013) catchments were used for verification of the suggested equations.

The columns Table (1) (from left to right) illustrate, respectively, the catchment name, stream order $(i)$, number of streams, mean stream length, mean stream area, mean stream slope, mean overland slope, $R_{B}, R_{L}, R_{A}, R_{S}$, and $R_{S O}$.

The Heng-Chi catchment is located in northern Taiwan and has an area of $53 \mathrm{~km}^{2}$ (Lee 1998). The Gagas catchment lies in the middle and outer range of the Himalayas in Uttarakhand State of India and has an area of $506 \mathrm{~km}^{2}$ (Kumar and Kumar 2008). The Kasilian Catchment is located between $53^{\circ} 18 \mathrm{E}$ and $53^{\circ} 30 \mathrm{E}$ longitudes and $35^{\circ} 58 \mathrm{~N}$ to $36^{\circ} 7 \mathrm{~N}$ latitudes in the north of Iran and has an area of $67.8 \mathrm{~km}^{2}$. Figure (1) shows the Gagas and Kasilian catchments. 
Hydrol. Earth Syst. Sci. Discuss., doi:10.5194/hess-2016-153, 2016

Manuscript under review for journal Hydrol. Earth Syst. Sci.

Published: 20 April 2016

(c) Author(s) 2016. CC-BY 3.0 License.
Hydrology and

Earth System

Sciences

Discussions

203

204

205

Table 1. GP of twelve case study catchments

\begin{tabular}{|c|c|c|c|c|c|c|c|c|c|c|c|}
\hline \multirow{2}{*}{$\begin{array}{l}\text { Catchment } \\
\text { Name }\end{array}$} & \multicolumn{11}{|c|}{ Geomorphologic parameters } \\
\hline & Order & $N_{i}$ & $\overline{L_{i}}$ & $\overline{A_{i}}$ & $\overline{S_{c}}$ & $\overline{S_{o}}$ & $R_{B}$ & $R_{L}$ & $R_{A}$ & $R_{S}$ & $R_{S O}$ \\
\hline \multirow[t]{4}{*}{ 1. Gagas } & 1 & 121 & 1.74 & 3.02 & 0.172 & 0.810 & 4.8 & 2.4 & 5.4 & 0.4 & 2.6 \\
\hline & 2 & 23 & 3.04 & 18.58 & 0.141 & 0.655 & & & & & \\
\hline & 3 & 6 & 7.63 & 79.22 & 0.041 & 0.172 & & & & & \\
\hline & 4 & 1 & 23.4 & 506 & 0.017 & 0.065 & & & & & \\
\hline \multirow[t]{4}{*}{ 2. Heng-Chi } & 1 & 30 & 0.66 & 1.043 & 0.087 & 0.450 & 3.3 & 2.6 & 4 & 0.6 & 1.1 \\
\hline & 2 & 6 & 2.74 & 6.919 & 0.050 & 0.419 & & & & & \\
\hline & 3 & 2 & 1.6 & 19.9 & 0.012 & 0.349 & & & & & \\
\hline & 4 & 1 & 4.97 & 53.23 & 0.012 & 0.347 & & & & & \\
\hline \multirow[t]{4}{*}{ 3. Kasilian } & 1 & 42 & 1.6 & 0.915 & 0.241 & 0.345 & 3.5 & 1.5 & 4.3 & 0.4 & 1.1 \\
\hline & 2 & 11 & 1.79 & 4.813 & 0.070 & 0.297 & & & & & \\
\hline & 3 & 3 & 2.45 & 20.75 & 0.047 & 0.263 & & & & & \\
\hline & 4 & 1 & 4.65 & 67.8 & 0.008 & 0.261 & & & & & \\
\hline \multirow[t]{4}{*}{ 4. San-Hsia } & 1 & 69 & 0.92 & 1.15 & 0.161 & 0.314 & 4.2 & 2.9 & 5 & 0.4 & 1.1 \\
\hline & 2 & 16 & 2.08 & 4.99 & 0.092 & 0.203 & & & & & \\
\hline & 3 & 3 & 3.88 & 18.15 & 0.037 & 0.364 & & & & & \\
\hline & 4 & 1 & 17.8 & 125.9 & 0.013 & 0.293 & & & & & \\
\hline \multirow[t]{4}{*}{ 5. Al-Badan } & 1 & 41 & 1.38 & 1.37 & 0.170 & 0.140 & 4 & 1.5 & 4.5 & 1 & 1.7 \\
\hline & 2 & 6 & 3.2 & 10.12 & 0.092 & 0.062 & & & & & \\
\hline & 3 & 2 & 5.03 & 40.73 & 0.140 & 0.051 & & & & & \\
\hline & 4 & 1 & 3.17 & 85 & 0.135 & 0.029 & & & & & \\
\hline \multirow[t]{4}{*}{ 6. Al-Faria } & 1 & 49 & 1.03 & 0.937 & 0.154 & 0.117 & 4 & 1.5 & 4.3 & 1.1 & 1.6 \\
\hline & 2 & 8 & 2.12 & 6 & 0.085 & 0.058 & & & & & \\
\hline & 3 & 3 & 3.5 & 19.4 & 0.161 & 0.033 & & & & & \\
\hline & 4 & 1 & 2.62 & 64 & 0.125 & 0.031 & & & & & \\
\hline \multirow[t]{3}{*}{ 7. Al-Malaqi } & 1 & 62 & 1.92 & 1.81 & 0.146 & 0.140 & 9 & 1.3 & 17 & 0.8 & 4.3 \\
\hline & 2 & 16 & 2.61 & 5.83 & 0.122 & 0.063 & & & & & \\
\hline & 3 & 1 & 3.21 & 185 & 0.081 & 0.010 & & & & & \\
\hline \multirow[t]{3}{*}{ 8. Debarwa } & 1 & 23 & 2.26 & 5.6 & 0.032 & 0.135 & 4.9 & 3 & 6 & 0.6 & 1.2 \\
\hline & 2 & 6 & 4.2 & 27.8 & 0.018 & 0.091 & & & & & \\
\hline & 3 & 1 & 17.7 & 195 & 0.010 & 0.098 & & & & & \\
\hline \multirow[t]{4}{*}{ 9. Gherghera } & 1 & 58 & 2.45 & 5.9 & 0.027 & 0.136 & 2.9 & 1.4 & 3.3 & 0.9 & 1.4 \\
\hline & 2 & 14 & 4.19 & 30.6 & 0.018 & 0.087 & & & & & \\
\hline & 3 & 5 & 10.2 & 101.0 & 0.010 & 0.064 & & & & & \\
\hline & 4 & 2 & 4.47 & 259.9 & 0.016 & 0.025 & & & & & \\
\hline
\end{tabular}


Hydrol. Earth Syst. Sci. Discuss., doi:10.5194/hess-2016-153, 2016

Manuscript under review for journal Hydrol. Earth Syst. Sci.

Published: 20 April 2016

\begin{tabular}{|c|c|c|c|c|c|c|c|c|c|c|c|}
\hline & 5 & 1 & 4.19 & 525.7 & 0.011 & 0.117 & & & & & \\
\hline \multirow[t]{4}{*}{ 10. Long chi } & 1 & 46 & 1.13 & 2.5 & 0.210 & 0.444 & 3.7 & 2.4 & 4 & 0.6 & 1.1 \\
\hline & 2 & 10 & 3.45 & 11.8 & 0.124 & 0.487 & & & & & \\
\hline & 3 & 4 & 3.19 & 32 & 0.073 & 0.514 & & & & & \\
\hline & 4 & 1 & 9.94 & 141.8 & 0.054 & 0.364 & & & & & \\
\hline \multirow[t]{4}{*}{ 11. Long men } & 1 & 58 & 1.31 & 2.74 & 0.560 & 0.256 & 4 & 2.2 & 4.7 & 0.9 & 1.8 \\
\hline & 2 & 13 & 2.48 & 12.3 & 0.560 & 0.123 & & & & & \\
\hline & 3 & 3 & 9.33 & 77.11 & 0.560 & 0.056 & & & & & \\
\hline & 4 & 1 & 8.18 & 246.8 & 0.385 & 0.056 & & & & & \\
\hline \multirow[t]{4}{*}{ 12. Chaukhutia } & 1 & 134 & 1.41 & 2.27 & 0.191 & 0.910 & 5.3 & 2.5 & 5.7 & 0.5 & 2.4 \\
\hline & 2 & 31 & 2.65 & 12.28 & 0.123 & 0.567 & & & & & \\
\hline & 3 & 7 & 7.21 & 60.18 & 0.041 & 0.174 & & & & & \\
\hline & 4 & 1 & 20.7 & 452.3 & 0.019 & 0.074 & & & & & \\
\hline
\end{tabular}

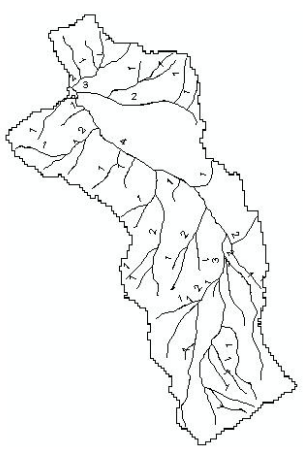

(a)

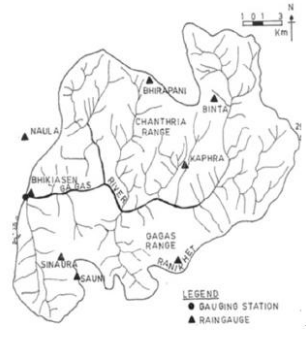

(b)

Fig. 1 a) Kasilian catchment stream network b) Gagas catchment

\section{Relationships of geomorphologic parameters}

\section{5.1. Estimation of bifurcation ratio $\left(\mathbf{R}_{\mathbf{B}}\right)$}

212 To estimate the bifurcation ratio of a catchment, the information concerning 80 watersheds with

213 areas between $1 \mathrm{~km}^{2}$ and $600 \mathrm{~km}^{2}$ were used which had known values of $R_{B}$ and area, with the

214 presumption that $R_{B}$ is a function of two variables, catchment area $(A)$ and the main stream

215 length $(L)$. With the help of SPSS18 software and using the information of 37 catchments an

216 optimum relation was obtained as: 
218 Admittedly, the value of $R_{B}$ was not dependent on $L$. The correlation coefficient of the fitted

219

220

221

222

223

224

225

226

227

228

229

230

231

232

233

234

235

236

237

238

239 equation is 0.8 and the real mean bifurcation ratio of the catchments is 4 . Eq. (12) indicates that in small catchments with area less than $200 \mathrm{~km}^{2}$, the value of $R_{B}$ runs between 3.47 and 4 . It is suggested that Eq. (12) be applied to catchments of areas beneath $600 \mathrm{~km}^{2}$. It should be noted that, regarding Eq. (7) and $\mathrm{R}_{\mathrm{B}}$, the values of $N_{i}$ are calculated for $i \leq \Omega . \Omega$ is the maximum order of the catchment. $N_{i=\Omega}=1$ is considered and $N_{i-1}=R_{B} N_{i}, i \leq \Omega$.

\subsection{Computation of stream-length Ratio $\left(R_{L}\right)$}

To calculate the length ratio $R_{L}$, it was taken as a function of the main stream length and the whole catchment area. The fitted regression equation for the nine selected catchments according to Table (1) is, as follows:

$R_{L}=2.59 L^{0.41} A^{-0.2}$

The correlation coefficient is equal to 0.91 . Based on Eq. (8) and $\mathrm{R}_{\mathrm{L}}$, the values of $\overline{L_{c_{i}}}$ are calculated for $i \leq \Omega . \overline{L_{c \Omega}}=L$ is considered and $\overline{L_{c_{i-1}}}=\overline{L_{c_{i}}} / R_{L}, i \leq \Omega$.

\subsection{Computation of area ratio $\left(R_{A}\right)$}

The area ratio was assumed to be a function of the bifurcation ratio and the length ratio with fitted equation:

$R_{A}=0.597 R_{B}^{1.553} R_{L}^{-0.177}$

The correlation coefficient is $0.99 \cdot \overline{A_{\Omega}}=A$ is considered and $\overline{A_{i-1}}=\overline{A_{i}} / R_{A}, i \leq \Omega$.

\subsection{Computation of stream slope ratio $\left(R_{S}\right)$}

Stream slope ratio was assumed to be a function of $R_{B}, R_{L}$, and $R_{A}$. Equation (15), having correlation coefficient 0.79 , represents the fitted regression relation for the data.

$R_{S}=1.198 R_{B}{ }^{1.26} R_{L}^{-0.97} R_{A}^{-1.04}$ 
Hydrol. Earth Syst. Sci. Discuss., doi:10.5194/hess-2016-153, 2016

Manuscript under review for journal Hydrol. Earth Syst. Sci.

Published: 20 April 2016

(c) Author(s) 2016. CC-BY 3.0 License.
241

242

243

244

245

246

247

248

249

250

251

252

253

254

255

256

257

258

\subsection{Computation of overland slope ratio $\left(\boldsymbol{R}_{S o}\right)$}

A nonlinear regression equation consisting of the parameters $R_{B}, R_{L}, R_{A}$, and $R_{S}$ was used to calculate the slope ratio of the overland plane with the fitted relation:

$R_{S O}=0.366 R_{B}^{2} R_{L}^{-0.58} R_{A}^{-0.66}$

The correlation coefficient of Eq. (16) is 0.93, and there is no strong correlation between $R_{S O}$ and $R_{S}$. By the Eqs. (16) and (11) the slope of overland planes of the catchment could be obtained. It is to be noted that the Eqs. (12) to (16) which are gained via the information about nine catchments may be calibrated by adding more data. Given that the length of the main river and the area in all catchments are known, the $R_{B}, R_{L}, R_{A}, R_{S}$, and $R_{S O}$ ratios can be calculated by Eqs. (12) to (16).

The area of the catchment, the length and slope of the main river could be determined from the simple topographic maps of the catchment. If a catchment has a maximum stream order $\Omega$, it is inferred that the stream should be located at the end of the catchment with the mean slope $\left(\overline{S_{c_{\Omega}}}\right)$ and the mean slope of the lateral overland planes $\left(\overline{S_{o_{\Omega}}}\right)$. For instance, Fig. 2 shows a small catchment with three subcatchment (I, II, III). The maximum stream order is two $(\Omega=2)$. The subcatchment III is created with two lateral overland planes and stream III is positioned at the end of the main catchment. Fig. 2 shows the mean slope of the stream $\operatorname{III}\left(\overline{S_{c_{2}}}\right)$ and mean slope of the two lateral overland planes $\left(\overline{S_{o_{2}}}\right)$.

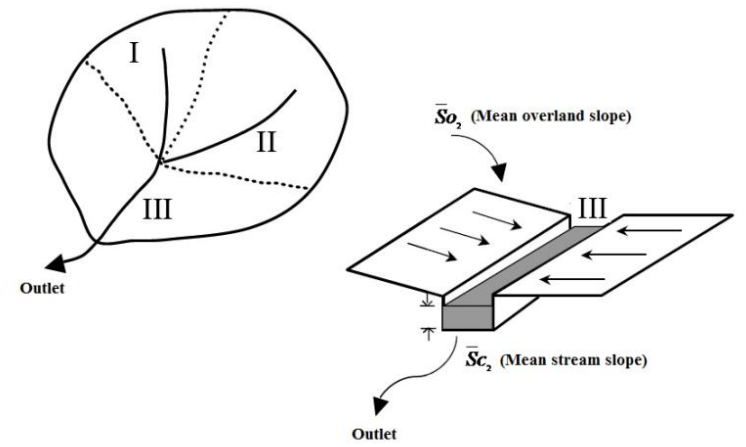


Hydrol. Earth Syst. Sci. Discuss., doi:10.5194/hess-2016-153, 2016

Manuscript under review for journal Hydrol. Earth Syst. Sci.

Published: 20 April 2016

(c) Author(s) 2016. CC-BY 3.0 License.
Hydrology and

Earth System

Sciences

Discussions

Fig. 2. Catchment with maximum stream order 2

260

261 If the values of the $\overline{S_{c_{\Omega}}}, \overline{S_{o_{\Omega}}}, R_{S}$ and $R_{S O}$ are known, with regard to Eqs. (10) and (11), the

262 value of the $\overline{S_{c_{i}}}$ and $\overline{S_{o_{i}}}$ are computable for lower orders $i<\Omega\left(\overline{S_{c_{i-1}}}=\overline{S_{c_{i}}} / R_{S}, \overline{S_{O_{i-1}}}=\overline{S_{O_{i}}} R_{S O}\right)$.

263

264

265

266

267

268

269

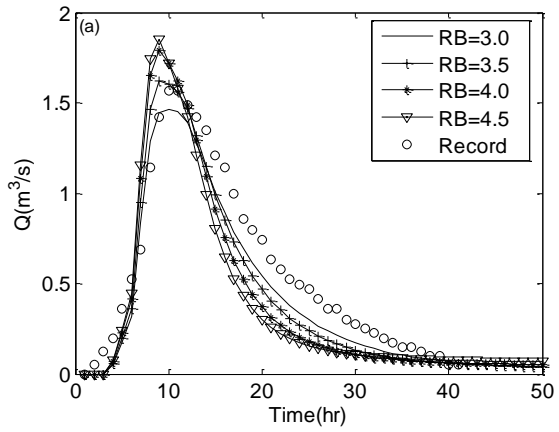

\section{Effect of ratios $R_{B}, R_{L}, R_{A}, R_{S}$ and $R_{S o}$ on DRH} catchment was utilized. May, 1993.

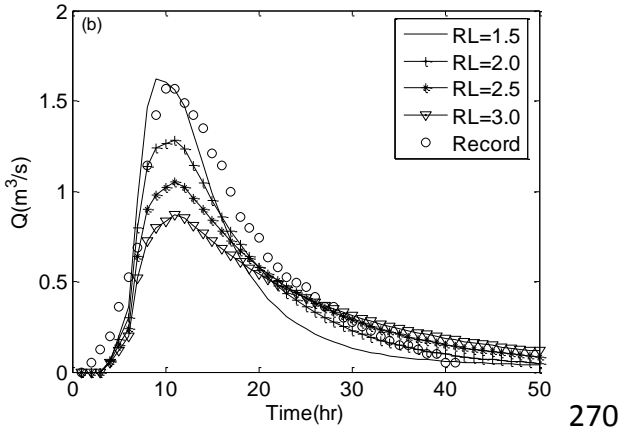

271

272 The values of bifurcation coefficient $3,3.5,4$, and 4.5 with 0.5 units increment were considered

273

274

275

276

277

278

In the previous section of this study, empirical equations were presented to obtain geomorphologic ratios. Now, we apply the GIUH model to look into sensitivity analysis of these ratios and their effects on DRH and on peak flood. To this end, the information of the Kasilian

Fig. (3a) illustrates the effect of bifurcation ratio upon DRH of the Kasilian catchment on $4^{\text {th }}$

Fig. 3. Effect of $R_{B}$ and $R_{L}$ on DRH of the Kasilian catchment

$$
\text { for the Kasilian catchment, and the number of streams and the values of input parameters into }
$$
GIUH model were computed and inserted to the model. The effect of $R_{B}$ on shape of hydrograph and peak of the runoff is seen in Fig. (3a).The results of the model are compared with those of recorded runoff hydrographs.

To determine the effect of different values of $R_{B}$ on the peak of runoff, the following equation of relative sensitivity was used: 
Hydrol. Earth Syst. Sci. Discuss., doi:10.5194/hess-2016-153, 2016

Manuscript under review for journal Hydrol. Earth Syst. Sci.

Published: 20 April 2016

(c) Author(s) 2016. CC-BY 3.0 License.
Hydrology and

Earth System

Sciences

Discussions

$279 \quad S_{r}=\frac{O_{2}-O_{1}}{P_{2}-P_{1}}(\bar{P} / \bar{O})$

280

281

282

283

284

285

286

287

288

289

290

291

292

where $O$ and $P$ represent particular model outputs and parameters, respectively. So, $S_{r}$ gives the percentage change in $O$ for a $1 \%$ change in $P . \bar{P}$ is given by $\left(P_{1}+P_{2}\right) / 2$ and $\bar{O}$ is given by $\left(O_{1}+O_{2}\right) / 2$. Results confirmed that the least computational error in peak discharge relative to the observed peak discharge was shown by $R_{B}=3.5$ with $3.5 \%$. The actual $R_{B}$ for the Kasilian catchment is also 3.5. The mean relative sensitivity of $R_{B}$ derived from Eq. (17) is 0.56 .

Fig. (3b) shows the effect of $R_{L}$ on DRH of the Kasilian catchment. The values of this ratio were taken as $1,1.5,2$, and 2.5 with a 0.5 increment. According to the results, $R_{L}=1.5$ has given the least error in peak discharge with $3.6 \%$ value. The actual $R_{L}$ of the catchment is 1.46 , and the mean relative sensitivity of $R_{L}$ amounts to 0.92 . The larger the value of $R_{L}$, the higher peak error. The runoff is affected more by length ratio relative to bifurcation ratio, a fact seen also in Fig. (3). The next section of the paper was dedicated to the effects of area ratio on the peak of runoff. The values of area ratio were regarded to be between 3 and 6 with 1 unit increment values. Figure (4) depicts the effect of area ratio on DRH.

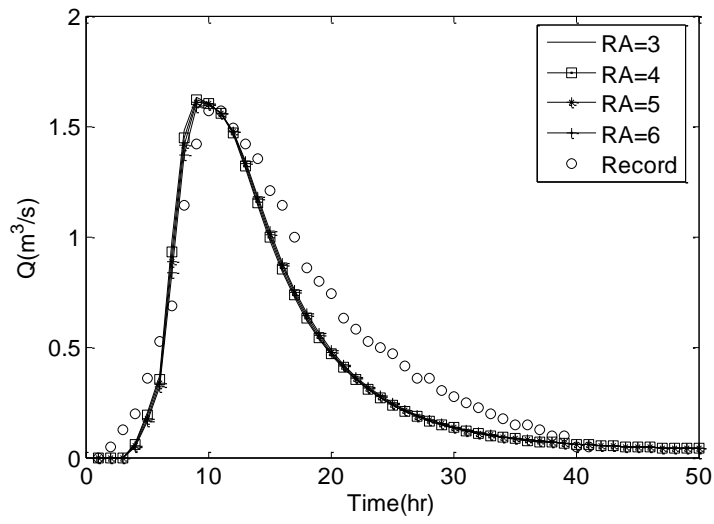

Fig.4. Effect of area ratio on DRH of the Kasilian catchment

As indicated by the results, the area ratio has had a slight effect on the runoff peak, so that alterations of this ratio do not noticeably influence the shape of hydrograph and flood peak.

Fig. (5a) shows how $R_{S}$ affects DRH for the values $0.1,0.4,0.7$, and 1 with a 0.3 increment. 

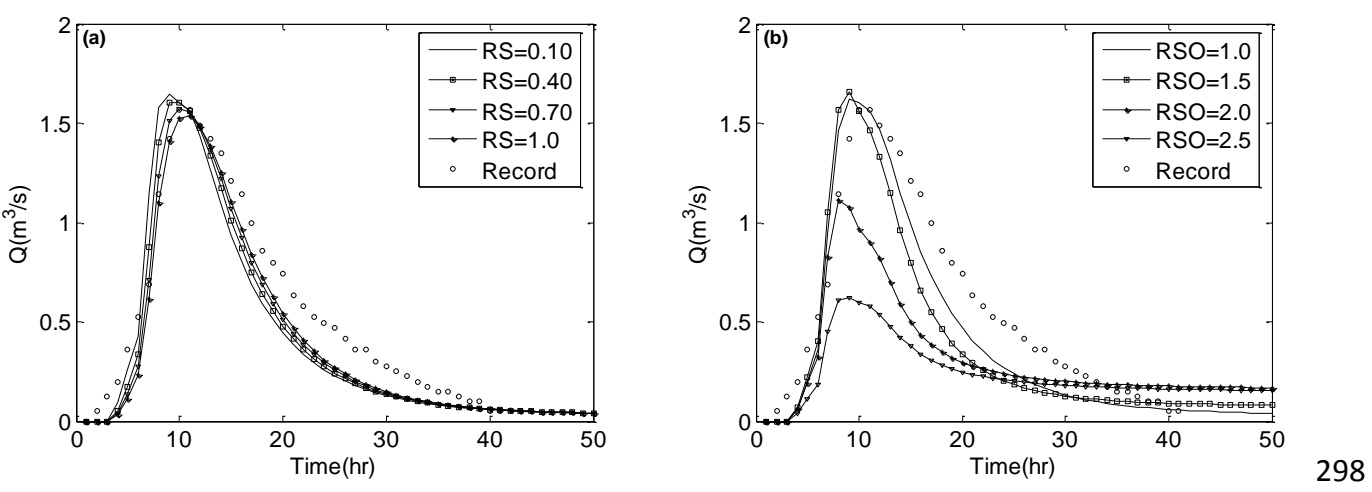

Fig. 5. Effect of $R_{S}$ and $R_{S O}$ on DRH of the Kasilian catchment

The least error is 0.47 which corresponds to the ratio (0.7) while the actual slope ratio of the Kasilian catchment is 0.38 . Also, the mean relative sensitivity ratio is 0.042 . The results indicate that this parameter has little effect on runoff peak, too.

Figure (5b) shows the influence of $R_{S O}$ on DRH for values of 1, 1.5, 2, and 2.5 with increment as 0.5 . The least error relates to the ratio 1 which is $3.54 \%$, whilst that of Kasilian catchment would be 1.1, and the mean relative sensitivity ratio 1.33 . According to the results, the parameter $R_{S O}$ has remarkable effect on runoff peak.

According to the overall results, the relative sensitivity ratio of $R_{B}, R_{L}, R_{A}, R_{S}$, and $R_{S O}$ is 0.56 , $0.92,0.01,0.042$, and 1.33 respectively. The most effect concerns, correspondingly to the overland slope ratio, length ratio, bifurcation ratio, slope ratio, and area ratio.

To calculate the value of $P_{x_{i} x_{j}}$ in Eq. (1) the following equation is used:

$P_{x_{i} x_{j}}=N_{i, j} / N_{i}$

where $N_{i, j}$ is number of $i$ th order stream contributing the flow to $j$ th order stream; $N_{i}$ is the number of $i$ th order channel. The value of $N_{i}$ is computable by the bifurcation ratio, but to obtain the parameter $N_{i, j}$ the following equation is suggested:

$$
N_{i, j}=2 N_{i} \exp (-0.64 j)
$$


Hydrol. Earth Syst. Sci. Discuss., doi:10.5194/hess-2016-153, 2016

Manuscript under review for journal Hydrol. Earth Syst. Sci.

Published: 20 April 2016

(c) Author(s) 2016. CC-BY 3.0 License.
Hydrology and Earth System Sciences

Discussions

(c) (i)

317

318 which is obtained through nonlinear regression of the stream network data based on

319

320

321

322

323

324

325

326

327

328

329 geomorphologic parameters of the Kasilian and the Gagas catchments. In the catchments possessing DEM one needs to delineate stream network and order them by GIS software, however, calculation of $N_{i, j}$ should be done manually and rendered by GIS operator which is a time-consuming and difficult task.

\section{Verification}

In the previous sections, equations were proffered for computation of stream-order-law ratios based on GP in nine different catchments in the world. For verification of the results of the regression equations the GP of three catchments Gagas, Heng-Chi, and Kasilian were applied.

Table (2) lists the GP as well as stream-order-law ratios of the three selected catchments using Eqs. (12) to (16). The table (2) also provides the observed values of stream ratios and their computational errors.
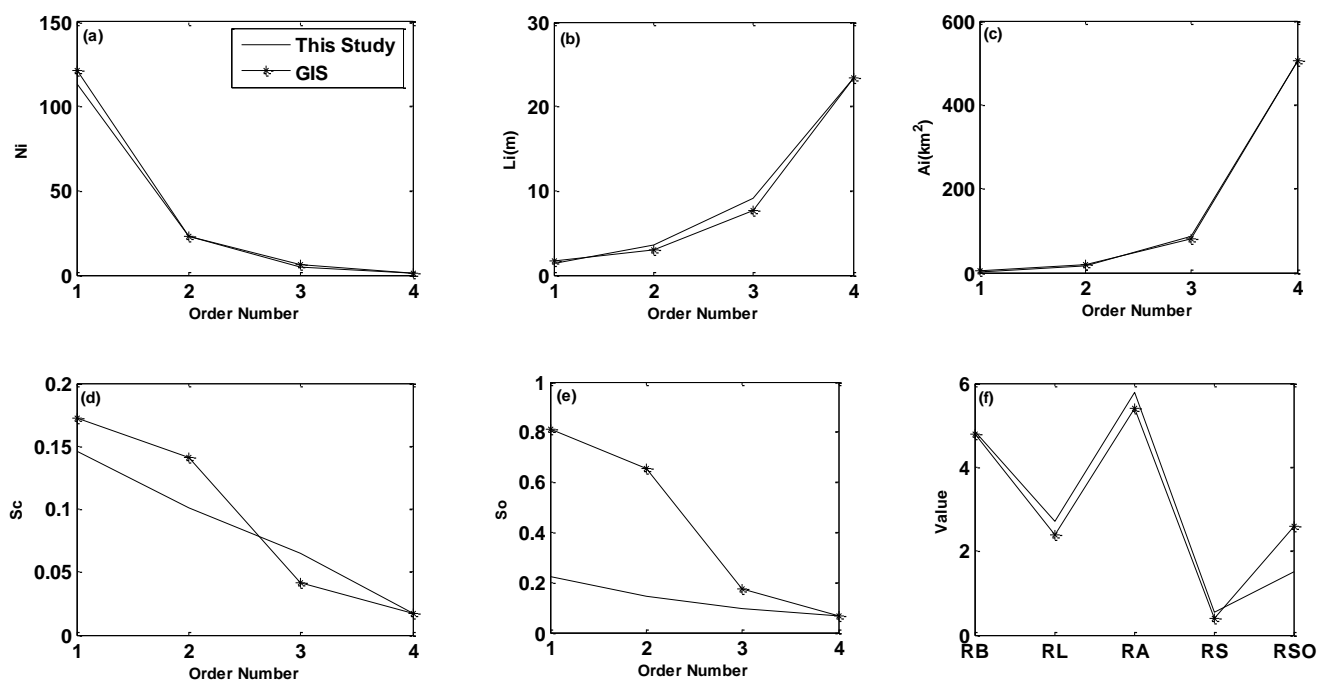
Hydrol. Earth Syst. Sci. Discuss., doi:10.5194/hess-2016-153, 2016

Manuscript under review for journal Hydrol. Earth Syst. Sci.

Published: 20 April 2016

(c) Author(s) 2016. CC-BY 3.0 License.
Hydrology and

Earth System

Sciences

Discussions

\begin{tabular}{|c|c|c|c|c|c|c|c|c|c|c|c|}
\hline \multirow{2}{*}{$\begin{array}{l}\text { Catchment } \\
\text { Name }\end{array}$} & \multicolumn{11}{|c|}{ Geomorphologic parameters } \\
\hline & Order & $N_{i}$ & $\overline{\overline{L_{i}}}$ & $\overline{\overline{A_{i}}}$ & $\overline{\overline{S_{c}}}$ & $\overline{\overline{S_{o}}}$ & $R_{B}$ & $R_{L}$ & $R_{A}$ & $R_{S}$ & $R_{S O}$ \\
\hline \multirow[t]{4}{*}{ 1. Gagas } & 1 & 113 & 1.38 & 2.6 & 0.146 & 0.222 & 4.84 & 2.72 & 5.78 & 0.53 & 1.5 \\
\hline & 2 & 23 & 3.54 & 15.1 & 0.101 & 0.147 & & & & & \\
\hline & 3 & 5 & 9.10 & 87.5 & 0.065 & 0.098 & & & & & \\
\hline & 4 & 1 & 23.40 & 506.0 & 0.017 & 0.065 & & & & & \\
\hline GIS Results & & & & & & & 4.80 & 2.40 & 5.40 & 0.40 & 2.60 \\
\hline$\%$ Error & & & & & & & 0.40 & 13.7 & 7.6 & 21.0 & 41.4 \\
\hline \multirow[t]{4}{*}{ 2. Heng-Chi } & 1 & 47 & 0.32 & 1.0 & 0.104 & 0.654 & 3.61 & 2.26 & 3.80 & 0.68 & 1.2 \\
\hline & 2 & 13 & 1.34 & 3.7 & 0.060 & 0.530 & & & & & \\
\hline & 3 & 4 & 2.43 & 14.0 & 0.031 & 0.429 & & & & & \\
\hline & 4 & 1 & 4.97 & 53.2 & 0.012 & 0.347 & & & & & \\
\hline GIS Results & & & & & & & 3.30 & 2.60 & 4 & 0.60 & 1.10 \\
\hline$\%$ Error & & & & & & & 9.4 & 13.7 & 5.0 & 13.3 & 9.1 \\
\hline \multirow[t]{4}{*}{ 3. Kasilian } & 1 & 49 & 0.49 & 1.1 & 0.109 & 0.563 & 3.65 & 2.09 & 3.92 & 0.72 & 1.3 \\
\hline & 2 & 13 & 1.03 & 4.4 & 0.073 & 0.436 & & & & & \\
\hline & 3 & 4 & 2.19 & 17.3 & 0.038 & 0.337 & & & & & \\
\hline & 4 & 1 & 4.65 & 67.8 & 0.008 & 0.261 & & & & & \\
\hline GIS Results & & & & & & & 3.5 & 1.5 & 4.3 & 0.4 & 1.1 \\
\hline$\%$ Error & & & & & & & 4.3 & 43.2 & 8.8 & 89.5 & 18.2 \\
\hline
\end{tabular}

336 Figs 6, 8 depict the GIS based and computational GP concerning the three case study 337 catchments.
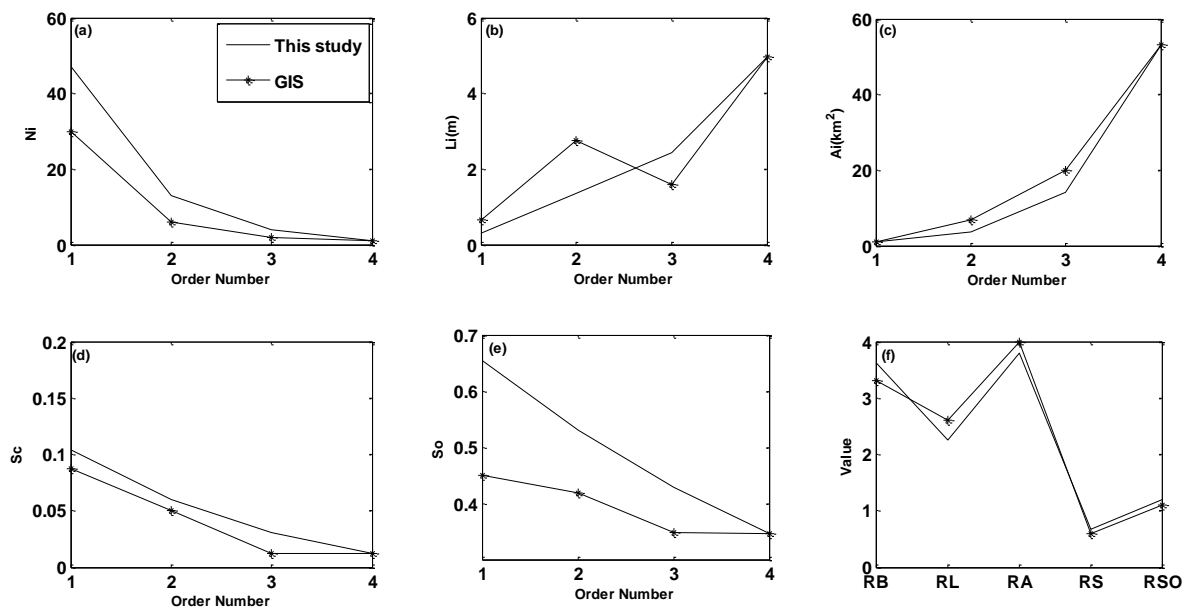
Hydrol. Earth Syst. Sci. Discuss., doi:10.5194/hess-2016-153, 2016

Manuscript under review for journal Hydrol. Earth Syst. Sci.

Published: 20 April 2016

(c) Author(s) 2016. CC-BY 3.0 License.
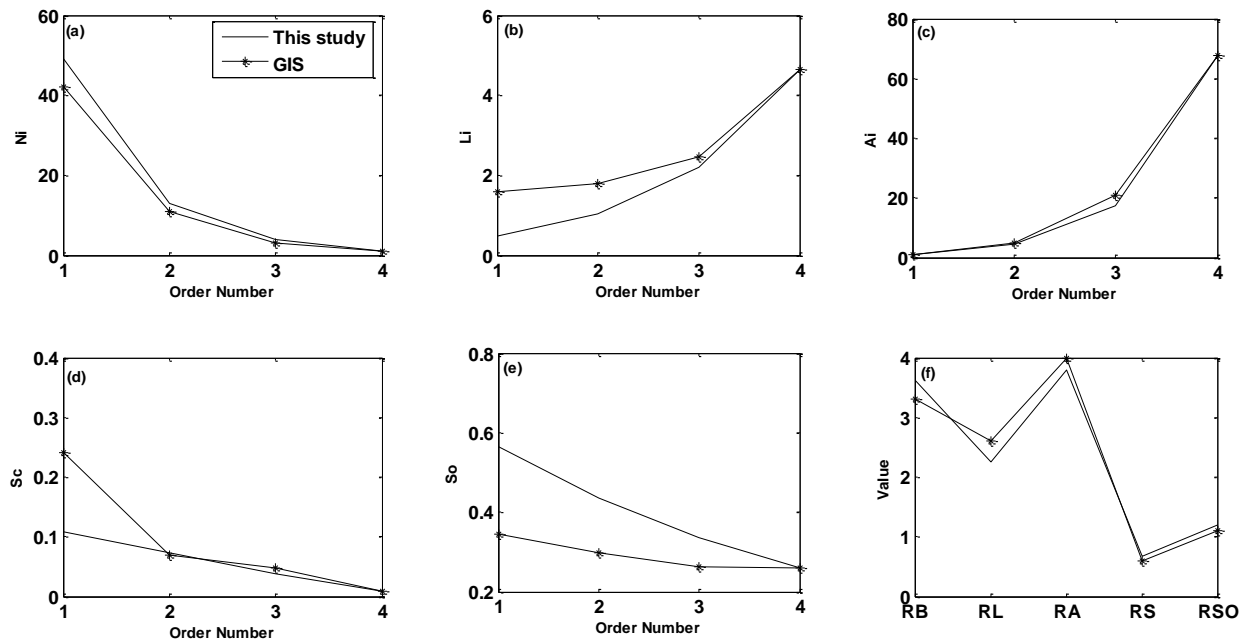

340

341

342

343

344

345

346

347

348

349

350

351

352

353

354

355

356

Fig.8. Verification of GP in Kasilain catchment

The mean errors of regression equations in estimation of $R_{B}, R_{L}, R_{A}, R_{S}$, and $R_{S O}$ in the three selected catchments are, respectively, $4.7 \%, 23.5 \%, 7.1 \%, 41.3 \%$, and $22.9 \%$.

The greatest errors of the model emerged in estimation of, respectively, $R_{S}, R_{L}, R_{S O}, R_{A}$, and $R_{B}$. As observed in Fig. (5a), the stream slope ratio has a slight affect on runoff, so its error could be ignored. Regarding high sensitivity of the length and overland slope ratios their errors range from 23 to 24 percent and it is recommended that the joint effects of all the ratios on DRH of the selected catchments be considered.

In the previous sections, the influences of GP on runoff were pondered separately, and the GP of the three catchments were estimated via the regression equations. To study accuracy of the estimations more deeply it is better to estimate the DRH using GIUH model. For this purpose, taking the information about excess rainfall hyetograph and recorded runoff of the Kasilian and the Heng-Chi catchments into consideration, we turn to verification of the predicted runoff for the two catchments.

The model GIUH was employed in two cases, one in which geomorphologic parameters are GIS based and the other where empirical regression equations (GIS-unsupported) are concerned for 
Hydrol. Earth Syst. Sci. Discuss., doi:10.5194/hess-2016-153, 2016

Manuscript under review for journal Hydrol. Earth Syst. Sci.

Published: 20 April 2016

(c) Author(s) 2016. CC-BY 3.0 License.
Hydrology and

Discussions

(c) $\underset{\mathrm{BY}}{(i)}$

357 the Kasilian and the Heng-Chi catchments. The results of the model in each case were compared

358 with those of observed runoff recorded. Since the observed runoff and rainfall data of Gagas

359 catchment were not available, this catchment was dispensed in verification phase. Figure 9

360 shows the results of GIUH model for DRH estimation in Kasilian catchment for two events on

$36110^{\text {th }}$ May 1992 and $4^{\text {th }}$ May1993. Also, Fig. (10) illustrates those in Heng-Chi catchment for two

362 events July 1996 and October 2000.
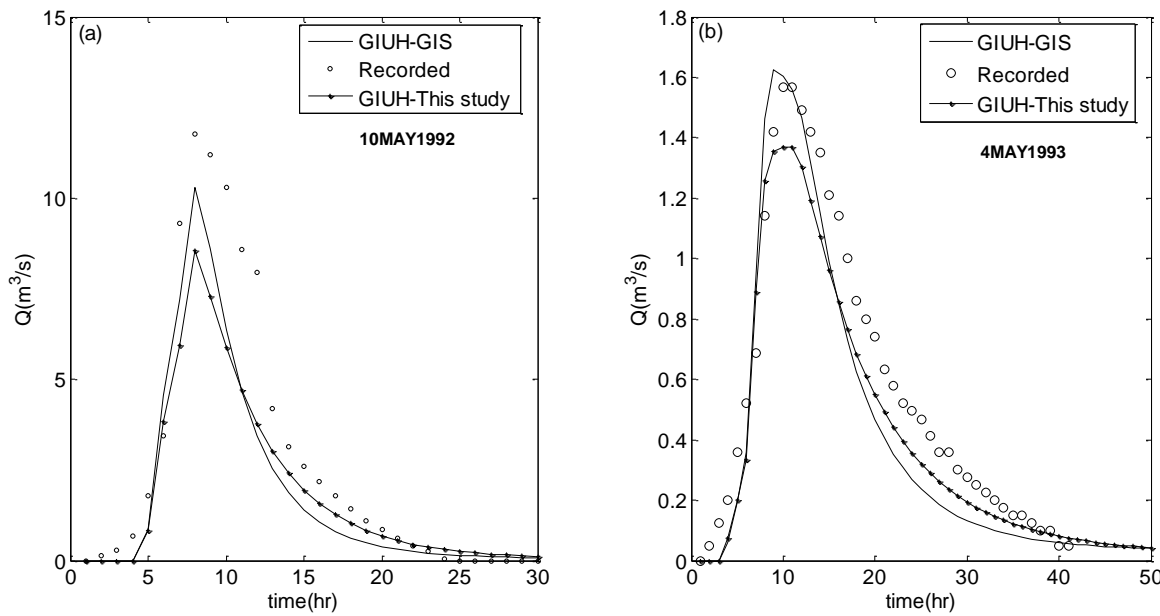

Fig.9. Estimation of Kasilian DRH by GIUH model
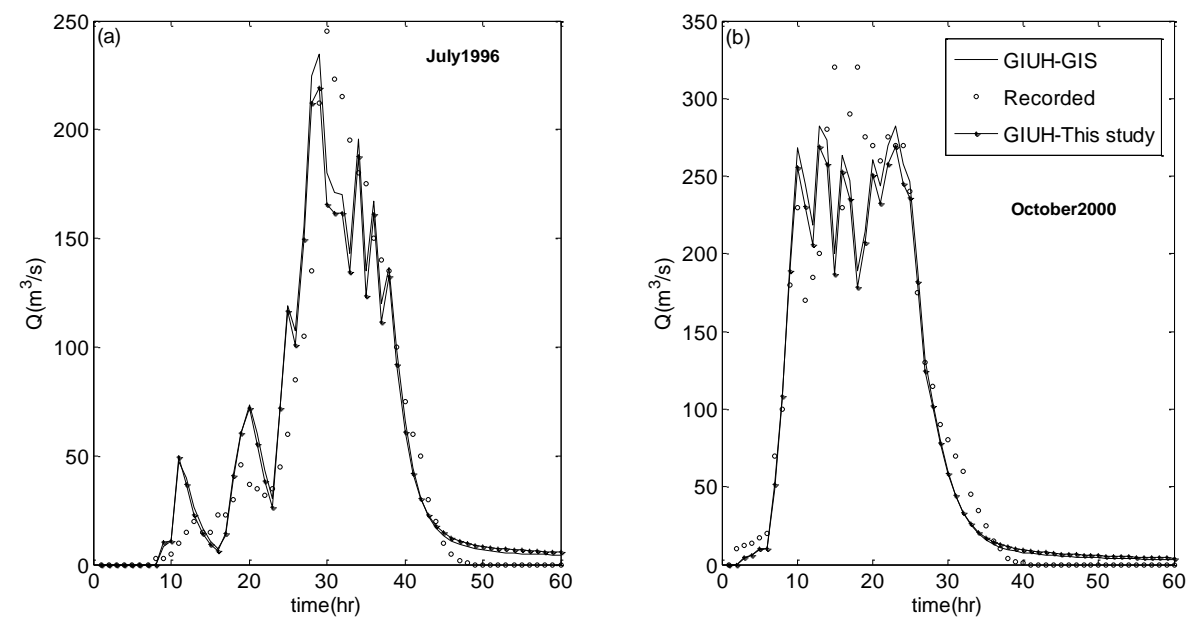
Hydrol. Earth Syst. Sci. Discuss., doi:10.5194/hess-2016-153, 2016

Manuscript under review for journal Hydrol. Earth Syst. Sci.

Published: 20 April 2016

(C) Author(s) 2016. CC-BY 3.0 License.
Hydrology and

Earth System

Sciences

Discussions

Fig.10. Estimation of Heng-Chi DRH by GIUH model

366

367 To validate the fitness of the model for the Kasilian and Heng-Chi catchments, three common

368 statistical measures were used, the coefficient of efficiency $(C E)$, Root mean square error

369 (RMSE), and Relative error in peak (REP).

370 Estimation of these three parameters is carried out by the following equations:

$371 C E=1-\frac{\sum_{t=1}^{n}\left[Q_{r}-Q_{s}\right]^{2}}{\sum_{t=1}^{n}\left[Q_{r}-\overline{Q_{r}}\right]^{2}}$

$372 \quad R M S E=\left[\frac{1}{n} \sum_{i=1}^{n}\left(Q_{r}-Q_{s}\right)^{2}\right]^{0.5}$

373

374

$R E P=100 \times\left[Q_{p_{s}}-Q_{p_{r}}\right] / Q_{p_{r}}$

375 where $Q_{r}$ is the recorded discharge at time $t ; Q_{s}$ is the simulated discharge at time $t ; \bar{Q}_{r}$ is the

376 mean recorded discharge during the storm event; $n$ is the number of discharge records during the

377 storm event; $Q_{p_{s}}$ is the peak discharge of the simulated hydrograph and $Q_{p_{r}}$ is the recorded

378 peak discharge.

379 Table (3) gives the values of REP, CE, and RMSE calculated for the two selected catchments in 380 GIS-supported and GIS-unsupported (this study) cases.

Table 3. Validation result of the GIUH model

\begin{tabular}{cccc}
\hline July1996 & $R E P \%$ & $C E$ & $R M S E$ \\
\hline GIS & 4.18 & 0.87 & 24.54 \\
This study & 10.62 & 0.86 & 25.44 \\
\hline October 2000 & & & \\
GIS & 11.81 & 0.93 & 31.22 \\
This study & 15.99 & 0.92 & 32.25 \\
\hline 10 May 1992 & & & \\
GIS & 12.68 & 0.81 & 1.13 \\
This study & 27.33 & 0.76 & 1.26 \\
\hline 4 May 1993 & & &
\end{tabular}




\begin{tabular}{cccc} 
GIS & 3.5 & 0.87 & 0.10 \\
This study & 12.6 & 0.91 & 0.10 \\
\hline
\end{tabular}

383 It is concluded that the computational error values of runoff peak $(R E P \%)$ that could be inferred 384 (in this study) for the four rainfall-runoff events are, on average, 10\% more than the error resulting from actual information (GIS support). As seen in Figs (9) and (10), the results of the GIUH model in the two cases concerning GIS and empirical equations are very close to each other. $C E$ and $R M S E$ are near-valued as well. The mean $C E$ of the model was computed for the four events as 0.87 which is a satisfactory value.

\section{Summary and conclusion}

In this research, experimental equations were presented to work out geomorphologic parameters of watersheds of less than $600 \mathrm{~km}^{2}$ area. These equations are offered in accordance with the nonlinear regression method fitted to the geomorphologic parameters of nine different catchments of the world. The equations were taken under verification in three other selected catchments, and their results were compared with those calculated from GIS. Finally, direct runoff hydrograph was estimated by GIUH with regard to the geomorphologic data computed for the three catchments, and then compared to the observed values. Sensitivity of bifurcation ratio, length ratio, area ratio, stream slope ratio, and overland slope ratio to runoff of Kasilian catchment were investigated. It is shown that the relative sensitivity of $R_{B}, R_{L}, R_{A}, R_{S}$, and $R_{S O}$ was $0.56,0.01,0.92,0.042$, and 1.33 , respectively. The greatest effect was related to, respectively, the overland slope ratio, length ratio, and bifurcation ratio, and the least effect was related to area ratio, and streams slope ratio.

The geomorphologic parameters of three catchments Gagas, Heng-Chi, and Kasilian were determined based on the experimental equations given in this research, and compared with their actual results. The average errors of the model in estimation of $R_{B}, R_{L}, R_{A}, R_{S}$, and $R_{S O}$ in the three case study catchments were $4.7 \%, 23.5 \%, 7.1 \% .41 .3 \%$, and $22.9 \%$, respectively.

Lastly, the estimated geomorphologic parameters was input into the GIUH model and the values of direct runoff hydrograph of two catchments Kasilian and Heng-Chi were calculated and compared with those of observed runoff. According to the results, the computational error values 
Hydrol. Earth Syst. Sci. Discuss., doi:10.5194/hess-2016-153, 2016

Manuscript under review for journal Hydrol. Earth Syst. Sci.

Published: 20 April 2016

(c) Author(s) 2016. CC-BY 3.0 License.

\section{0-References} contract.

of runoff peak $(R E P \%)$ for the four rainfall-runoff events are, on average, $10 \%$ more than the error resulting from actual information (GIS-Supported). The results of the GIUH model in the two cases concerning GIS and without GIS are very close to each other. $C E$ and RMSE in the two cases are near-valued as well. The mean coefficient of efficiency of the model was computed for the four events as equal to 0.87 .

9-Acknowledgements: The authors would like to thank Estahban Branch, Islamic Azad University for the financial support of this research, which is based on a research project

Alemngus, A, Mathur, B.S (2014) GEOMORPHOLOGIC INSTANTANEOUS UNIT HYDROGRAPHS FOR RIVERS IN ERITREA (EAST AFRICA), Journal of Indian Water Resources Society, Vol. 34, No. 1.

Choi, Y, Lee, G, Kim, J (2011). Estimation of the Nash model parameter based on concept of geomorphologicdispersion. J HydrolEng 16(10), 806-817.

Chang, C.-H and Lee, K. T (2008) Analysis of geomorphologic and hydrological characteristics in watershed saturated areas using topographic-index threshold and geomorphology-based runoff model, Hydrol. Process., 22, 802-812.

Gupta, V.K, Waymire, E and Wang, C.T (1980) A representation of an instantaneous unit hydrograph from geomorphology. Water Resour. Res. 16 (5), 855-862.

Horton, R. E (1932) Drainage-basin characteristics, Eos Trans. AGU, 13,350- 361.

Horton, R. E (1945) Erosional development of streams and their drainage basins: Hydrophysical approach to quantitative morphology, Geol. Soc.Am. Bull., 56, 275- 370.

Kumar, R, Chatterjee, C , Singh, RD, Lohani, AK and Kumar, S (2004) GIUH based Clark and Nash models for runoffestimation for an ungauged basin and their uncertainty analysis. Int $\mathbf{J}$ River Basin Manag, 2(4):281-190.

Kumar, R, Chatterjee, C, Singh, RD, Lohani, AK and Kumar, S (2007) Runoff estimation for an ungauged catchmentusing geomorphologic instantaneous unit hydrograph (GIUH) models. Hydrol Process 21(14):1829-1840. 
Hydrol. Earth Syst. Sci. Discuss., doi:10.5194/hess-2016-153, 2016

Manuscript under review for journal Hydrol. Earth Syst. Sci.

Published: 20 April 2016

(c) Author(s) 2016. CC-BY 3.0 License.

438 Kumar, A, Kumar, D (2008) Predicting direct runoff from hilly watershed using geomorphology

439 and stream-order law ratios: case study. J Hydrol Eng, 13(7), 570-576.

440 Kumar, A (2015) Geomorphologic Instantaneous Unit Hydrograph Based Hydrologic Response 441 Models for Ungauged Hilly Watersheds in India, Water Resources Management, February, Vol $442 \quad 29,3,863-883$.

443 Lee, K.T., Yen, B.C., 1997. Geomorphology and kinematic-wave based hydrograph derivation. 444 J. Hydrol. Eng. ASCE, 123 (1), 73-80.

445 Lee, K.T (1998) Generating design hydrographs by DEM assisted geomorphic runoff simulation: 446 a case study. J. Am. Water Resour. Assoc. 34 (2), 375-384.

447 Lee, K. T, and Chang, C. H (2005) Incorporating subsurface-flow mechanism into 448 geomorphology-based IUH modeling. Journal of Hydrology, 311:91-105.

449 Rodriguez-Iturbe, I, Valdes, J.B (1979) The geomorphologic structure of hydrologic response. 450 Water Resour. Res. 15 (6),1409-1420.

451

452

453

Rodriguez-Iturbe, I, Gonzalez-Sanabria, M, Bras, R.L (1982). Ageomorphoclimatic theory of the instantaneous unit hydrograph. Water Resour. Res. 18 (4), 877-886.

Smart, J. S (1972) Channel networks., Advances in hydroscience, Vol.8, V. T. Chow, ed., Academic Press, Inc., San Diego, Calif., 305-346.

Strahler, A. N (1952) Hypsometric (area-altitude) analysis of erosionaltopology, Bull. Geol. Soc. Am., 63, 1117-1142.

Strahler, A. N (1957) Quantitative analysis of watershed geomorphology, Trans. AGU, 38(6), 913-920.

Strahler, A. N (1964) Quantitative geomorphology of drainage basins and channel networks, in Handbook of Applied Hydrology, edited by Ven te Chow, pp. 4 -39, McGraw-Hill, New York.

Sabzevari, T, Fattahi, M.H, Mohammadpour, R and Noroozpour, S (2013) Prediction of surface and subsurface flow in catchments using the GIUH, under publication. Journal of Flood Risk Management. , Vol 6. Issue 2, 135-145.

Sabzevari, T, Noroozpour, S (2014) Effects of hillslope geometry on surface and subsurface flows, Hydrogeology Journal,, Vol22,7, 1593-1604. 
Hydrol. Earth Syst. Sci. Discuss., doi:10.5194/hess-2016-153, 2016

Manuscript under review for journal Hydrol. Earth Syst. Sci.

Published: 20 April 2016

(c) Author(s) 2016. CC-BY 3.0 License.

466 Shadeed, S, Shaheen, H and Jayyousi, A (2007) GIS-BASED KW-GIUH HYDROLOGICAL

467 MODEL OF SEMIARID CATCHMENTS: THE CASE OF FARIA CATCHMENT,

468 PALESTINE, The Arabian Journal for Science and Engineering, Volume 32, Number 1C.

469 Shuyou, C, Lee, K.T, Juiyi H, Xingnian, L, Huang, E and Yang, K (2010) Analysis of Runoff

470 in Ungauged Mountain Watersheds in Sichuan, China using Kinematic-wave-based GIUH

471 Model, Journal of Mountain Science, Vol 7,2, 157-166.

472 Yen, B. C, and Lee, K. T (1997) Unit hydrograph derivation for ungauged watersheds by stream473 order laws, J. Hydrol. Eng., 2(1), 1-9. 